\title{
EVALUASI STRATEGI PEMASARAN \\ DALAM UPAYA MEMBANGUN LOYALITAS PENGGUNA \\ DI PERPUSTAKAAN UIN SUNAN KALIJAGA YOGYAKARTA DITINJAU DARI PENDEKATAN CUSTOMER RELATIONSHIP MANAGEMENT \\ Ratih Nurhidayah*
}

\begin{abstract}
This study aims to evaluate marketing strategy in efforts to build user loyalty at the Library of State Islamic University Sunan Kalijaga Yogyakarta based on Customer Relationship Management approach. The study is qualitative with evaluative approach. Data were collected through observation, interview and documentation methods and analyzd in two stages, before and after visiting the location of the study comprising data collection, data reduction, data presentation and conclusion. The study was also supported with quantitative data to assess score of evaluation result in the form of percentage. Test of data validity used credibility test using triangulation and membercheck. The result of the study showed that: (1) Internal communication patterns were built through interpersonal method via media; (2) Human resources in the Library consisted of librarians' group and structural staff; (3) The top products of the Library were technology-based services, Islamic collections, facilities and comfortable room; (4) Performance evaluation of the Library organization was carried out through monthly meeting forum and annual meeting at the end of the year; (5) Communication with the library users occured in interpersonal way, through social media and "Friends of the Library"; (6) Attitude and performance of the Library officerswere substandard and paying less attention to appearance; (7) The Library had extensive cooperation with various stakeholders. In conclusion, the marketing strategy in efforts to build user loyalty at the Library of State Islamic University Sunan Kalijaga Yogyakarta was $86 \%$ in accordance with the concept of Customer Relationship Management.
\end{abstract}

Keywords: service marketing, library marketing, Customer Relationship Management

\section{PENDAHULUAN}

Kemajuan teknologi menghadirkan era baru dalam dunia informasi. Seperti yang ditulis oleh Artana dalam Majalah OnlineVisi Pustaka (2003:1) bahwa untuk memenuhi tuntutan dari pengguna informasi, maka perpustakaan harus mampu bersaing untuk memberikan pelayanan informasi yang relevan bagi pengguna. Selanjutnya perpustakaan harus mampu mengembangkan layanan serta membina hubungan baik dengan pengguna agar tidak ditinggalkan oleh penggunanya.

Perpustakaan merupakan lembaga yang bergerak pada bidang jasa. Lasa HS (2005:49-50) memaparkan bahwa Perpustakaan adalah organisasi nonprofit yang bertugas untuk memberikan pelayanan informasi kepada masyarakat umum dengan mengutamakan kepuasan pengguna. Berbicara masalah kepuasan, Kotler (2007:35-37) menyebutkanbahwa perusahaan jasa menerapkan strategi pemasaran untuk menganalisis kondisi pasar, membina hubungan baik, membangun merek yang kuat, menyerahkan serta mengkomunikasikan nilai sebagai evaluasi kerja, kemudian mampu mencapai kepuasan serta membangun hubungan jangka panjang. Dengan demikian dapat dipahami bahwa strategi pemasaran jasa juga dapat diterapkan di perpustakaan. Perpustakaan yang menyusun strategi pemasaran jasa tepat pada sasaran pasar akan menumbuhkan eksistensi dan meraih citra positif dari perpustakaan. Purwono (2013:103) menyebutkan bahwa menciptakan serta membangun citra suatu perpustakaan merupakan hal yang sangat 
penting, agar loyalitas pengguna perpustakaan makin melekat sehingga pengguna tidak berpaling pada pelayanan lain.

Berbicara mengenai hubungan dả . loyalitas pengguna, Khomariah (2010:2) menyebutkan bahwa konsep Customer Relationship Management (CRM) merupakan sebuah konsep dalam mendukung aktifitas pemasaran berpusat pada pengguna yang menumbuhkan sifat loyal dan akan membuat pengguna merasa bergantung dengan layanan yang diberikan. Disebutkan pula bahwa konsep CRM banyak diadopsi oleh perusahaan yang bergerak dalam pelayanan jasa. Oleh karena itu CRM sangat mungkin untuk diadopsi sebagai model dalam mendukung strategi pemasaran jasa perpustakaan. Pemasaran jasa yang dimulai dengan konsep CRM dianggap mampu menjadi modal awal untuk menghadapi daya saing pasar dari perpustakaan.

Perpustakaan UIN Sunan Kalijaga tergolong sebagai perpustakaan perguruan tinggi. Keberadaan Perpustakaan UIN Sunan kalijaga sangat berperan penting dalam mendukung visi, misi dan tujuan dari lembaga induknya. Dalam melaksanakan perannya, Perpustakaan UIN Sunan Kalijaga selalu berusaha mengembangkan layanan untuk memenuhi kebutuhan informasi penggunanya. Jika peneliti amati, Perpustakaan UIN Sunan Kalijaga sudah dibantu oleh sistem terpadu berbasis komputer, seperti sistem temu kembali informasi dan akses jaringan internet.

Berdasarkan hasil dokumentasi pada website Perpustakaan UIN Sunan Kalijaga, diperoleh informasi bahwa Perpustakaan UIN Sunan Kalijaga sudah terakreditasi A. Selain itu dituliskan pula bahwa perpustakaanperpustakaan lain melakukan studi banding dan menjalin kerjasama dengan perpustakaan UIN Sunan Kalijaga. Namun, peningkatan prestasi perpustakaan dan adanya pelayanan berbasis teknologi ternyata tidak menjamin kepuasan pengguna perpustakaan.

Berdasarkan hasil pra penelitian pada 7 Oktober 2013, peneliti mengamati terdapat pengguna yang tidak menemukan koleksi dalam rak. Namun, petugas tidak berusaha mencarikan koleksi dengan mekanisme pelayanan jasa yang tepat. Pustakawan juga kurang memperhatikan keperluan dan keinginan pengguna datang ke perpustakaan. Sehingga peneliti memahami bahwa hal tersebut membuat hubungan pustakawan dengan pengguna tidak terjalin dengan baik. Pengguna menjadi kurang tertarik mengkomunikasikan kendala yang dialami kepada petugas perpustakaan. Hal ini ditakutkan akan menciptakan citra negatif, membuat pengguna menjadi tidak loyal kemudian beralih ke sumber informasi lain, seperti toko buku atau perpustakaan lain.

Oleh karena itu, berangkat dari identifikasi masalah di lapangan serta ditinjau dari beberapa teori yang menguatkan, maka peneliti berkeinginan untuk mengkaji lebih dalam tentang "Evaluasi Strategi Pemasaran Dalam Upaya Membangun Loyalitas Pengguna Di Perpustakaan UIN Sunan Kalijaga Yogyakarta Ditinjau Dari Pendekatan Customer Relationship Management".

\section{Rumusan Masalah}

Bagaimana strategi pemasaran dalam upaya membangun loyalitas pengguna di Perpustakaan Universitas Islam Negeri Sunan Kalijaga Yogyakarta jika ditinjau dari pendekatan Customer Relationship Management?

\section{LANDASAN TEORI}

\section{Evaluasi}

Evaluasi sering digunakan untuk meninjau kembali dan menilai sesuatu yang sudah ada. Sesuai dengan pernyataan Arikunto (2010:36-37) yang menuliskan bahwa evaluasi merupakan serangkaian proses pengumpulan data atau informasi untuk dibandingkan dengan kriteria, kemudian dapat ditarik sebuah simpulan untuk perbaikan. Pernyataan tersebut didukung dengan pendapat Wirawan (2012:7) yang menyebutkan bahwa evaluasi merupakan tindakan untuk mengumpulkan, menganalisis dan menyajikan informasi yang bermanfaat mengenai objek evaluasi, kemudian menilai dan membandingkannya dengan indikator evaluasi dan hasilnya digunakan sebagai bahan pengambilan keputusan mengenai objek evaluasi. 


\section{Pemasaran}

\section{Pengertian Pemasaran}

Pemasaran merupakan ujung tombak dari aktifitas suatu perusahaan. Sarwono dalam e-journal Innofarm (2010:1) menyebutkan bahwa pemasaran memberi perhatian pada hubungan timbal balik yang dinamis antara produk dan jasa-jasa perusahaan, keinginan serta kebutuhan konsumen dan kegiatan-kegiatan para pesaing pasar.

\section{Pemasaran Jasa}

Seseorang sering menyebut jasa sebagai wujud dari manfaat suatu objek atau hasil dari pelayanan. William J. Stanton sebagaimana dikutip oleh Sunyoto (2013:186-187) menyebutkan bahwa jasa merupakan kegiatan yang dapat diidentifikasikan, namun bersifat tak teraba dan direncanakan untuk pemenuhan kepuasan pada konsumen. Sebagaimana diungkapkan oleh Boyd (2000:283) bahwa pemasaran jasa merupakan pelopor dari terwujudnya suatu pelayanan berkualitas serta ketergantungan dalam jangka panjang terhadap produk tertentu.

Jadi, peneliti memahami bahwa pemasaran jasa merupakan suatu upaya untuk memahami kebutuhan seseorang serta membuat seseorang tertarik menggunakan pelayanan tertentu sehingga seseorang dapat merasakan manfaat dari pelayanan atau barang yang diberikan.

\section{Strategi Pemasaran Jasa Perpustakaan}

Strategi adalah cara yang sering disusun dan dilakukan seseorang untuk menghasilkan sesuatu. Hover dalam Boyd (2000:29) menyebutkan bahwa dalam dunia marketing strategi(strategy) adalah pola fundamental dari tujuan sekarang dan yang direncanakan, pengerahan sumber daya, dan interaksi dari organisasi dengan pasar, pesaing, dan faktorfaktor lingkungan lain.Sebagaimana diungkapkan oleh Sulistyo-Basuki (1993:3) bahwa informasi dalam perpustakaan dapat dimanfaatkan seseorang untuk memperbaiki diri dan menambah pengetahuan. Oleh karena itu, perpustakaan harus mengingatkan masyarakat secara terus menerus akan keberadaan jasa perpustakaan, serta apa saja yang dapat dikerjakan atau yang disediakan perpustakaan untuk menciptakan sebuah lingkungan kehidupan perpustakaan yang baik.

\section{Loyalitas Pengguna}

Berbicara mengenai loyalitas pengguna, dalam istilah marketing hal ini sering disebut dengan customer loyality. Assauri (2012:1415) memaparkan bahwa loyalitas pengguna atau loyalitas pelanggan merupakan kecenderungan untuk memilih nilai organisasi yang ditawarkan di atas alternatif tawaran beberapa organisasi pesaing.Menurut Griffin (2005:31), karakteristik pengguna yang loyal adalah sebagai berikut:

1. Melakukan pembelian berulang secara teratur (makes reguler repeat purchase).

Dalam hal ini tingkat kepuasan pengguna terhadap perpustakaan akan mempengaruhi mereka datang kembali untuk menggunakan fasilitas perpustakaan.

2. Membeli di luar lini produk/jasa (purchases across product and service lines).

Dalam hal ini pengguna yang sudah percaya pada layanan perpustakaan tertentu dalam pemenuhan kebutuhan informasi maka akan tetap datang dan percaya dengan mengesampingkan urusan lain seperti halnya pelayanan.

3. Mereferensi perusahaan kepada orang lain, artinya menarik pelanggan baru untuk perusahaan (refers other).

Dalam hal ini pengguna yang loyal dengan sukarela merekomendasikan perpustakaan kepada teman-teman dan rekannya.

4. Menunjukkan kekebalan daya tarik dari pesaing (Demonstrates an immunity to the full of the competition).

Dalam hal ini pengguna tidak mudah terpengaruh oleh tarikan persaingan sumber informasi sejenis lainnya (seperti perpustakaan lain, toko buku, bahkan internet).

Dengan demikian, dapat dikatakan bahwa pengguna perpustakaan UIN Sunan Kalijaga Yogyakarta secara mayoritas adalah mahasiswa UIN Sunan Kalijaga Yogyakarta. Maka pengguna perpustakaan dapat digolongkan sebagai pengguna loyal perpustakaan yang secara dominan lebih 
memanfaatkan perpustakaan UIN Sunan Kalijaga dibanding perpustakaan lain.

\section{Customer Relationship Management (CRM) \\ Pengertian CRM}

Customer Relationship Management (CRM) merupakan salah satu konsep dalam bidang marketing. Jika diartikan dalam bahasaIndonesia adalah manajemen hubungan pelanggan. Berbicara tentang hal ini, Siahaan dalam Jurnal Pustaka (2008:81) menyebutkan bahwa CRM atau manajemen hubungan pelanggan merupakan suatu jenis manajemen yang secara khusus membahas teori mengenai penanganan hubungan antara perusahaan dengan pelanggannya dengan tujuan meningkatkan nilai perusahaan di mata pelanggan. CRM memerlukan fokus yang jelas dalam atribut pelayanan yang akan menghasilkan nilai kepada pelanggan sehingga akan tercipta loyalitas. Definisi tersebut, dịdukung oleh pendapat CatalánMatamoros (2012:1) yang menuliskan definisi CRM sebagai berikut.

"Customer relationship management (CRM) is a combination of people, processes and technology that seeks to understand a company's customers. It is an integrated approach to managing relationships by focusing on customer retention and relationship development. CRM has evolved from advances in information technology and organizational changes in customer-centric processes."

Artinya, bahwa CRM adalah kombinasi dari pelaku, proses dan teknologi yang bertujuan untuk memahami lebih dalam tentang pelanggan perusahaan. CRM merupakan pendekatan yang terintegrasi untuk mengelola hubungan dengan berfokus pada cara mempertahankan pelanggan dan mengembangkan hubungan dengan pelanggan. CRM telah berkembang seiring kemajuan teknologi informasi dan menuntut perubahan terhadap organisasi untuk melakukan pelayanan perpusat pada pengguna (customer-centric).

\section{Proses CRM}

Strauss \& Frost (2001) sebagaimana ditulis oleh Tjiptono (2014: 424) menyebutkan bahwa proses CRM meliputi tiga langkah utama sebagai berikut:

1. Identifikasi pelanggan, yang didasarkan pada informasi mengenai pelanggan individual yang diperoleh melalui berbagai sumber personal dan automated source, msalnya wiraniaga, staf layanan pelanggan, barcode scanner di gerai ritel, dan aktivitas website.

2. Diferensiasi pelanggan berdasarkan karakteristik, perilaku, kebutuhan, atau customer value. Dasar pemikirannya adalah bahwa setiap konsumen itu unik dan tidak semua pelanggan mempunya nilai yang sama untuk sebuah perusahaan. Dalam konsep CRM, perusahaan berusaha memanfaatkan teknologi mutakhir untuk mengidentifikasi high-value cuwtomers dan merespon kebutuhan mereka dengan penawaran secara real-time.

3. Customizing bauran pemasaran yang disesuaikan dengan tuntutan preferensi individual.

Proses CRM akan memperoleh keberhasilan jika didukung dengan faktorfaktor yang menunjang. Dalam hal ini Chaffey, et al. (2000) sebagaimana dikutip oleh Tjiptono (2014:427) menyebutkan bahwa faktor krusial dalam aplikasi CRM meliputi Lima I (5i) sebagai berikut:

1. Identification, yakni mempelajari karakteristik konsumen secara rinci (anggota buying centre dan power mereka)

2. Individualization, yaitu menyesuaikan penawaran perusahaan dengan karakteristik pelanggan individual.

3. Interaction, yakni membangun dan mempertahan komunikasi dua arah dengan pelanggan.

4. Integration, yaitu mengintegrasikan relasi dan pemahaman atas pelanggan ke dalam seluruh jajaran organisasi.

5. Integrity, menjaga privasi setiap pelanggan dan trust yang dibina dalam jangka panjang

\section{Model CRM di Perpustakaan}

Siahaan

(2008:83-85)

juga

menyebutkan bahwa untuk memudahkan proses analisis penerapan CRM di perpustakaan, dapat dibagi dalam dua (2) sisi

28 Berkala IImu Perpustakaan dan Informasi - Volume XI Nomor 1, 2015 
pembahasan, yaitu dari sisi internal dan sisi eksternal perpustakaan.

\section{Sisi Internal}

Sisi internal dapat meliputi; (1) proses komunikasi internal perpustakaan; (2) sumber daya manusia; (3) berbagai produk jasa layanan; dan (4) evaluasi kinerja organisasi.

a. Proses Komunikasi Internal Perpustakaan

Komunikasi internal ini dimaksudkan untuk menghubungkan antara kebutuhan organisasi dan kebutuhan karyawan akan keamanan.

b. Sumber Daya Manusia (SDM)

Keahlian, kemampuan, kekuatan, pengalaman dan potensi yang berupa sumber daya manusia harus dipergunakan dan dimanfaatkan secara maksimal dalam penyelenggaraan perpustakaan.

c. Jasa Layanan

Jasa layanan perpustakaan dapat diwujudkan dalam berbagai bentuk. Seperti layanan yang sesuai dengan kebutuhan, berlangsung cepat dan tepat sasaran, menarik dan menyenangkan, menimbulkan rasa simpati, mengundang rasa ingin kembali, ramah tamah, mengembangkan hal-hal yang baru/inovatif, bersifat informatif dan membimbing, mengarahkan tetapi tidak bersifat menggurui serta mampu menumbuhkan rasa percaya bagi pemakai dan bersifat mandiri.

d. Evaluasi kerja organisasi

Dengan adanya evaluasi yang benar-benar obyektif terhadap kinerja organisasi yang terus menerus akan diketahui kekurangan dan keberhasilan yang telah dicapai

\section{Sisi Eksternal}

Sisi eksternal dapat meliputi: (1) komunikasi dengan pengguna;

performance; (3) penyelenggaraan tugas.

a. Komunikasi dengan pengguna

Adanya komunikasi dengan pihak pengguna terkait segala bentuk perubahan yang ada di perpustakaan. Upaya ini dilakukan agar para pengguna mengetahui adanya produk layanan ataupun prosedur layanan yang baru.

b. Sikap dan Performance
Sikap merupakan salah satu unsur utama dalam pelayanan. Selain itu, penampilan fisik dan cara pustakawan melayani pengguna perpustakaan merupakan hal yang secara langsung akan dilihat dan diamati oleh pengguna. Dalam hal ini, SDM harus memiliki ciri khas pelayan jasa yang menarik dan unik (unique). Dalam Kamus Besar bahasa Indonesia unik diartikan memiliki ciri khusus sehingga nampak berbeda dari yang lain.

c. Penyelenggaraan tugas

Dalam menyelenggarakan tugas, fungsi serta berbagai program kegiatan perpustakaan tidak dapat bekerja sendiri, melainkan perlu menjalin mitra kerja dengan pihak lain. Oleh karena itu, perlu menjalin hubungan yang baik dengan mitra kerja atau stakeholder

Jadi, dari beberapa penjabaran di atas mengenai pendekatan CRM sebagai langkah untuk menyusun suatu strategi pemasaran perpustakaan dapat dilihat dari:

1. pola komunikasi internal perpustakaan;

2. sumber daya manusia yang ada di perpustakaan;

3. jasa dan layanan yang sudah dipasarkan oleh perpustakaann serta media pendukung;

4. upaya yang dilakukan dalam mengevaluasi kerja organisasi;

5. pola komunikasi dengan pengguna perpustakaan serta media pendukung;

6. sikap dan performance dalam melayani pengguna;

7. kerjasama yang dijalin oleh perpustakaan.

\section{METODE PENELITIAN}

Metode penelitian yang digunakan adalah diskriptif kualitatif dengan menggunakan pendekatan evaluatif. Penelitian dilaksanakan di Perpustakaan UIN Sunan Kalijaga dalam kurun waktu penelitian bulan November 2014 s.d. Januari 2015.

\section{Subyek dan Obyek Penelitian}

Pada penelitian ini yang menjadi subyek penelitian adalah Perpustakaan UIN Sunan Kalijaga Yogyakarta. Obyek dari penelitian ini adalah strategi pemasaran perpustakaan. 


\section{Informan dan Teknik Perrentuan Informan}

Pada penelitian ini informan penelitian ditetapkan menggunakan teknik snowbaill. sampling. Pada penelitian ini, peneliti akan menetapkan key person dengan pertimbangan sebagai berikut:

1. Masih menjabat sebagai staf Perpustakaan UIN Sunan Kalijaga Yogyakarta pada masa penelitian berlangsung;

2. Informan kunci merupakan petugas yang berinteraksi secara langsung dengan pengguna perpustakaan pada kesehariannya;

3. Informan mampu mengoperasikan teknologi informasiperpustakaan (komputer, otomasi perpustakaan, dan sosial media);

4. Informan faham tentang ruang lingkup pemasaran perpustakaan (analisis keb̧utuhan pengguna, pelayanan pengguna, pusat informasi perpustakan, kerjasama dan promosi).

Untuk itu, maka peneliti menetapkan Kepala Urusan bagian Layanan Informasi dan Promosi sebagai key person dalam penelitian ini.

\section{Tabel 1 Daftar Key Person}

\begin{tabular}{clc}
\hline No. & Nama & Jabatan \\
\hline 1. & IS & $\begin{array}{c}\text { Kepala Urusan Informasi dan } \\
\text { Promosi }\end{array}$ \\
\hline
\end{tabular}

*Sumber :http://www.lib.uin-suka.ac.id/

Key person merujuk informan lain guna dimintai data. Pada pelaksanaannya peneliti menetapkan data informan utamasejumlah lima orang petugas perpustakaan berdasarkan rujukan dari key person. Alasan peneliti hanya menetapkan lima orang karena pada pelaksanaannya, data yang didapat dari lima orang informan utama tersebut sudah dianggap jenuh sehingga dirasa cukup untuk dianalisis. Berikut merupakan lima orang informan utama dalam penelitian.

Tabel 2 Daftar Informan Utama

\begin{tabular}{cll}
\hline No. & Nama & \multicolumn{1}{c}{ Jabatan } \\
\hline 1 & WA & Kour Sirkulasi \\
\hline 2 & MW & Pustakawan \\
\hline
\end{tabular}

\begin{tabular}{cll}
\hline 3 & BHN & Kour Referensi dan Serial \\
\hline 4 & MYF & Staf Sistem Informasi \\
\hline 5 & SA & Kobid Layanan Teknis \\
\hline
\end{tabular}

*Sumber: Data hasil (2014)

Selanjutnya, peneliti juga dirujuk untuk melakukan kroscek data kepada mahasiswa sebagai berikut (nama sesungguhnya ada pada peneliti). Kroscek data dari mahasiswa dilakukan secara incidental yakni melakukan wawancara secara langsung dengan pengguna yang ditemui di tempat kejadian saat pengumpulan data berlangsung. Pada pelaksanaannya, setelah mengumpulkan data dari key person dan informan utama peneliti bertemu dengan tiga orang mahasiswa part time di Perpustakaan UIN Sunan Kalijaga Yogyakarta. Kemudian, peneliti juga menemui pengguna bukan part time. Setelah mendapatkan data dari tiga orang pengguna bukan part time pada saat pengumpulan data berlangsung, ternyata data sudah dianggap jenuh. Dengan demikian kroscek data dari enam mahasiswa (tiga part time dan tiga pengguna bukan part time) dianggap sudah cukup. Maka peneliti berhenti melakukan kroscek data dari mahasiswa.

Tabel 3 Daftar Informan Tambahan

\begin{tabular}{clc}
\hline No. & Nama & Jabatan \\
\hline 1 & NM & Mahasiswa Pengguna \\
\hline 2 & EP & Mahasiswa Pengguna \\
\hline 3 & AK & Mahasiswa Pengguna \\
\hline 4 & RY & Mahasiswa Part time \\
\hline 5 & QF & Mahasiswa Part time \\
\hline 6 & NT & Mahasiswa Part time \\
\hline *umber : data hasil (2014)
\end{tabular}

\section{Instrumen Penelitian dan Teknik Pengumpulan Data}

Pada penelitian ini yang menjadi instrumen penelitian adalah peneliti sendiri. Namun, saat berada di lapangan peneliti akan menggunakan variasi instrumen lain sebagai alat bantu mengumpulkan data diantaranya adalah Pedoman wawancara, Check-list, Camera Recorder (Kamera HP Samsung Galaxy Young GT-S6310), Pedoman Evaluasi yang dibuat berdasarkan Model Customer Relationship Management di Perpustakaan (Siahaan, 2008). 
Sedangkan dalam mengumpulkan data, peneliti menggunakan beberapa . teknik pengumpulan data kualitatif diantaranya sebagai berikut:

a) Wawancara, dalam penelitian ini peneliti melakukan wawancara dengan menggunakan jenis wawancara mendalam (in-depth interview).

b) Observasi, jenis observasi yang digunakan dalam penelitian ini adalah observasi partisipan. Peneliti menempatkan diri sebagai peneliti serta pengguna aktif di Perpustakaan UIN Sunan Kalijaga Yogyakarta.

c) Dokumentasi, teknik pengumpulan data berupa dokumentasi peneliti gunakan untuk memperoleh data yang sudah berwujud dokumen.

\section{Teknik Analisis Data}

Dalam penelitian ini, peneliti menggunakan dua prosedur sebagai metode analisis data. Dua prosedur tersebut adalah sebagai berikut:

Pada tahap teknik analisis data sebelum di lapangan peneliti melakukan grand-tourobservation dan grand-tour-question sebagai langkah awal/ pra observasi di perpustakaan UIN Sunan Kalijaga Yogyakarta pada 3 Oktober s.d. 14 November 2013 sebagai mahasiswa praktik. Kemudian peneliti sebagai pengguna aktif Perpsutakaan UIN Sunan Kalijaga melakukan pengumpulan data secara berangsur selama tahun 2014 .

\section{a. Model Milles and Huberman}

Pada penelitian ini, peneliti akan menggunakan teknik pengumpulan data di lapangan model Milles and Huberman dengan tahapan sebagai berikut.

1) Pengumpulan data di lapangan, peneliti mengumpulkan data secara menyeluruh sesuai dengan pedoman yang digunakan. Baik pedoman wawancara maupun pedoman evaluasi.

2) Reduksi data (Data Reduction),peneliti mengelompokkan data sesuai dengan tema dan kajian per-subjek.

3) Penyajian data (Data Display), peneliti mulai menyajikan data dalam bentuk pembahasan secara rinci.
4) Penarikan simpulan (Conclusion Drawing), peneliti membuat simpulan dari pembahasan dengan bahasa yang lebih ringkas dan dapat dimengerti sebagai hasil dari penelitian.

\section{Analisis Data Kuantitatif}

Analisis data kuantitatif merupakan upaya yang dilakukan peneliti setelah mendapatkan data-data dari lapangan. Hasil tinjauan dinyatakan dalam bentuk persentase kesesuaian data di lapangan dengan standar yang digunakan menggunakan rumus persentase sebagai berikut.

$$
\text { Persentase }=\frac{\sum \text { total jawaban }}{\text { skor maksimal }} \quad \times 100 \%
$$

Pada proses ini, hasil pengumpulan data yang sudah dinyatakan dalam bentuk persentase diukur menggunakan standart persentase nilai sebagaimana dinyatakan oleh Sudjana (2005: 107) sebagai berikut.

Tabel 4 Konversi Tingkat Pencapaian

\begin{tabular}{ccc}
\hline $\begin{array}{c}\text { Persentase } \\
(\%)\end{array}$ & Kualifikasi & Keterangan \\
\hline $90-100 \%$ & Sangat Baik & Sangat Sesuai \\
\hline $75-89 \%$ & Baik & Sesuai \\
\hline $65-74 \%$ & Cukup & Cukup Sesuai \\
\hline $55-64 \%$ & Kurang & Tidak Sesuai \\
\hline $0-54 \%$ & $\begin{array}{c}\text { Sangat } \\
\text { Kurang }\end{array}$ & $\begin{array}{c}\text { Sangat Tidak } \\
\text { Sesuai }\end{array}$ \\
\hline
\end{tabular}

\section{b. Uji Keabsahan Data}

Pada penelitian ini peneliti menggunakan beberapa teknik uji kredibilitas data sebagai berikut.

1. Triangulasi

Peneliti menggunakan triangulasi data untuk menguji kredibilitas keabsahan data. Uji keabsahan ditinjau menggunakan beberapa teknik triangulasi di antararanya adalah triangulasi sumber, triangulasi teknik, triangulasi waktu

2. Membercheck

Pada penelitian ini, peneliti memberikan membercheck kepada pemberi data setelah semua data yang didapatkan dari lapangan sudah ditarik simpulan oleh peneliti. Memberchek berupa transkrip hasil pengumpulan data yang 
dikroscek kembali oleh sumber data sebelum kemudian dibubuhi tanda tangan oleh sumber sata sebagai persetujuan keutuhan dan kesesuaian. data.

\section{HASIL DAN PEMBAHASAN}

Hasil evaluasi strategi pemasaran dalam upaya membangun loyalitas pengguna perpustakaan UIN Sunan Kalijaga Yogyakarta ditinjau dari pendekatan customer relationship managementdapat dijabarkan sebagai berikut.

\section{Sisi Internal}

\section{a. Komunikasi Internal Perpustakaan}

Komunikasi internal ditujukan kepada segala kepengurusan dalam perpustakaan. Siahaan (2008:83) menyebutkan bahwa komunikasi internal ini dimaksudkan untuk menghubungkan antara kebutuhan organisasi dan kebutuhan karyawan akan keamanan. Sehubungan dengan hal tersebut, berdasarkan hasil penelitian di Perpustakaan UIN Sunan Kalijaga Yogyakarta, dihasilkan bahwa komunikasi internal perpustakaan terjalin melalui adanya forum tertentu. Sehingga, segala permasalahan organisasi bisa disampaikan secara langsung melalui forum tersebut. rutin setiap satu bulan satu kali dalam waktu yang berbeda. Sedangkan forum pimpinan dilaksanakan ketika urgent saja.

Selain adanya sebuah forum, peneliti menganalisa bahwa komunikasi internal perpustakaan dalam kesehariannya diwujudkan melalui komunikasi dalam bentuk langsung maupun tidak langsung. Komunikasi langsung dilakukan secara interpersonal menyampaikan informasi kepada yangbersangkutan. Sedangkan untuk komunikasi tidak langsung disampaikan melalui beberapa media seperti pesan memo dalam kondisi urgent, melalui e-mail, dan melalui telepon baik ponsel pribadi maupun telepon kantor.

Sehubungan dengan komunikasi internal organisasi perpustakaan, Siahaan (2008:83) menyebutkan bahwa dalam komunikasi internal dapat mengkomunikasikan pesan secara Top down (pesan manajemen), Bottom Up (masukan, bukan hanya pesan-pesan karyawan namun segala sesuatu yang menyangkut karyawan) dan menyamping (melewati semua fungsi atau bagian, yang mempersatukan sebuah organisasi menjadi satu tim).

Jadi, dari hasil reduksi data di atas maka peneliti dapat menyimpulkan bahwa komunikasi internal perpustakaan UIN Sunan

Gambar 1 Komunikasi Internal

Perpustakaan UIN Sunan Kalijaga

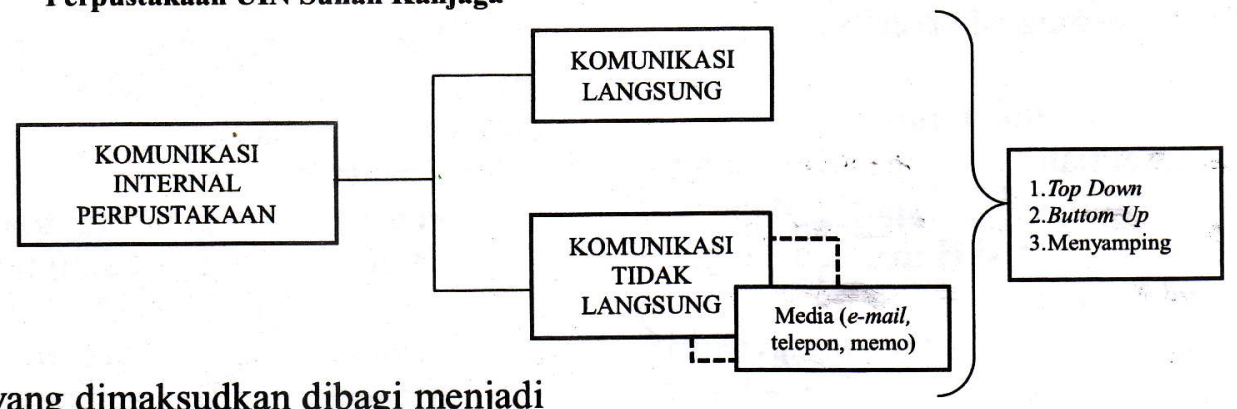

Forum yang dimaksudkan dibagi menjadi tiga buah forum yakni; (1) forum pimpinan yang terdiri dari kepala, wakil dan koordinator bidang; (2) forum koordinasi yang terdiri dari kepala, koordinator bidang, dan koordinator urusan; serta (3) forum umum yang terdiri dari kepala dan seluruh pegawai yang bekerja di perpustakaan kecuali tenaga mahasiswa part time. Forum koordinasi dan forum umum dilaksanakan

Kalijaga Yogyakarta diwujudkan dengan upaya menjaga komunikasi internal keseharian baik secara langsung maupun melalui media serta membentuk forum pertemuan rutin. Dengan demikian komunikasi internal sudah terpenuhi baik dari segi top down, buttom up maupun menyamping. 


\section{b. Sumber Daya Manusia Perpustakaan}

Sumber Daya Manusia (SDM) merupakan bagian dari tata kelola suatu lembaga informasi, termasuk perpustakaan. Berbicara masalah SDM, Siahaan (2008:84) memaparkan bahwa faktor manusia dalam manajemen merupakan unsur yang utama dan pertama karena segalasesuatunya bermula dari manusia dan berakhirpula pada manusia. Dalam hal ini keahlian, kemampuan,kekuatan, pengalaman dan potensi yang melekat pada SDM harus dipergunakandan dimanfaatkan secara maksimal dalampenyelenggaraan perpustakaan.

Pustakawan sebagai SDM yang mengelola suatu perpustakaan. Berdasarkan Undang-Undang Republik Indonesia Nomor 43 Tahun 2007 Tentang Perpustakaan, Pustakawan adalah seseorang yang memiliki kompetensi yang diperoleh melalui pendidikan dan/atau pelatihan kepustakawanan serta mempunyai tugas dan tanggung jawab untuk melaksanakan pengelolaan dan pelayanan perpustakaan.

Berdasarkan hasil reduksi data, peneliti menganalisa bahwa SDM di perpustakaan UIN Sunan Kalijaga Yogyakarta digolongkan menjadi dua golongan yakni: pendidikan dan pelatihan perpustakaan; serta (2) Kelompok Staf struktural yang belum memiliki SK tetap Pustakawan dari pemerintah namun bekerja di perpustakaan dan melaksanakan tugas sesuai arahan pustakawan.

Sehubungan dengan SDM, ditinjau dari segi keahlian, kemampuan, kekuatan, pengalaman dan potensi yang dimanfaatkan secara maksimal sebagaimana dipaparkan oleh Siahaan (2008:84). Kemudian, dari hasil reduksi data, peneliti menganalisa bahwa terdapat penggolongan kelompok pustawan yang dituntut potensial dengan berbagai kegiatan serta mampu membimbing golongan staf struktural dalam pelaksanaan tugas. Demikian, adanya penggolongan maupun kesenjangan latar pendidikan tidak menjadi penghambat kerja tim untuk tetap menghasilkan produk serta layanan jasa dan informasi yang terbaik.

Dengan kata lain dapat diartikan bahwa SDM yang dimiliki oleh perpustakaan UIN Sunan Kalijaga memiliki kebermanfaatan yang tidak diragukan baik dari segi keahlian, kemampuan, kekuatan, pengalaman maupun potensi. Berikut merupakan ilustrasi struktur

\section{Gambar 2 Struktur SDM UIN SUKA}

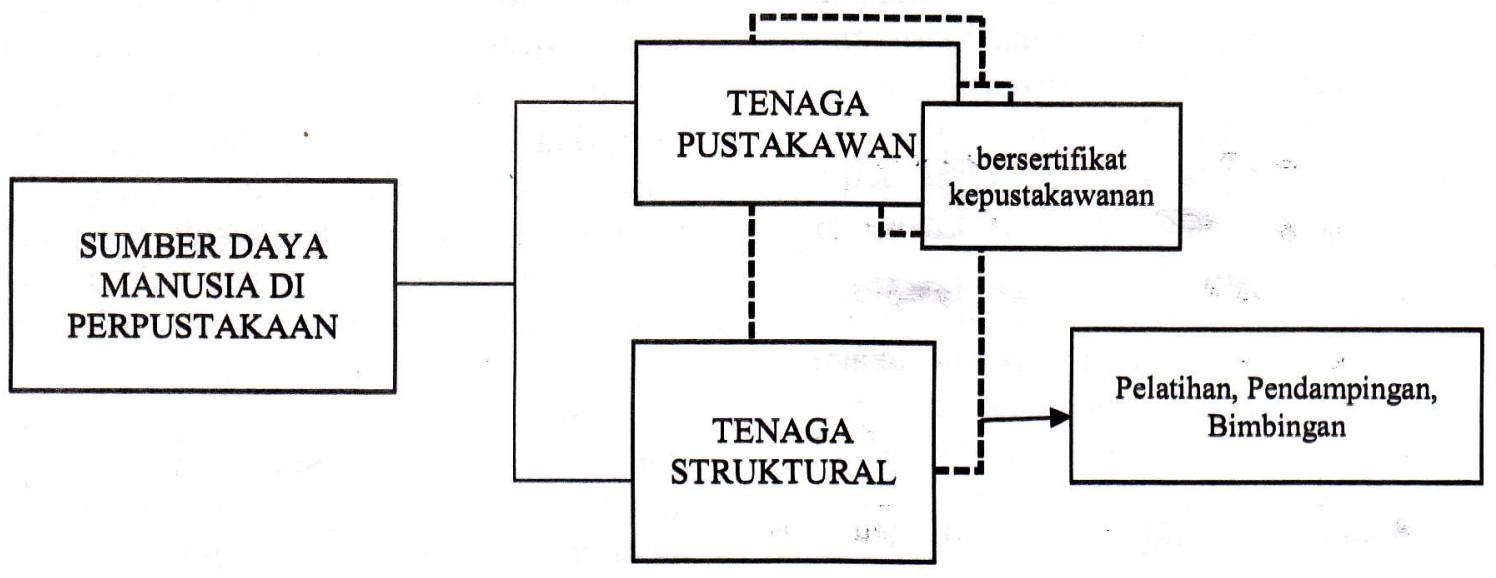

(1) Kelompok Pustakawan yang memiliki SK dari pemerintah dengan latar belakang pendidikan kepustakawanan baik melalui S1 Ilmu Perpustakaan maupun
Sumber Daya Manusia (SDM) yang dimiliki Perpustakaan UIN Sunan Kalijaga Yogyakarta. 


\section{c. Jasa dan Layanan Unggulan di Perpustakaan}

Jasa tidak berwujud namun dapat dirasakan. Dalam hal ini, disebutkan oleh William J. Stanton sebagaimana dikutip oleh Sunyoto (2013:186-187) bahwa jasa merupakan kegiatan yang dapat diidentifikasikan namun bersifat tak teraba dan direncanakan untuk pemenuhan kepuasan pada konsumen. Perpustakaan adalah salah satu jenis lembaga yang bergerak di bidang Jasa. Dipaparkan oleh Lasa HS (2005:49-50) bahwa Perpustakaan adalah organisasi nonprofit yang bertugas untuk memberikan pelayanan informasi kepada masyarakat umum dengan mengutamakan kepuasan pengguna.

Dari pemaparan di atas, dapat dipahami bahwa kepuasan pengguna menjadi ujung tombak para penyedia jasa agar pengguna jasa dapat menggunakan secara terus menerus. Penggunaan jasa secara terus menerus dapat didefinisikan sebagai loyalitas pengguna. Disebutkan oleh Griffin (2005:31) bahwa pengguna yang loyal melakukan pembelian berulang secara teratur (makes reguler repeat purchase). Dalam hal ini tingkat kepuasan pengguna terhadap perpustakaan akanmempengaruhi mereka datang kembali untuk menggunakan fasilitas perpustakaan.

Peneliti mengamati bahwa jasa dan layanan yang ada di Perpustakaan UIN Sunan Kalijaga Yogyakarta dilengkapi dengan sistem berbasis teknologi informasi canggih. Sistem berbasis teknologi informasi tersebut bersifat mandiri dan terkontrol. Hal ini membuat jasa yang ditawarkan terkemas lebih menarik serta layanan mampu mencapai tingkat efektif dan efisien.

Dalam menghadapi daya saing penyedia referensi keislaman, perpustakaan UIN senantiasa unggul dan tetap menjadi pilihan utama dalam kelengkapan studi keislaman. Hal ini dibuktikan dengan adanya ruang referensi keislaman di lantai 2 dan ruang sirkulasi khusus koleksi keislaman di lantai 3 Perpustakaan UIN Sunan Kalijaga Yogyakarta. Jasa dan layanan menarik diwujudkan dengan pemanfaatan teknologi informasi serta kelengkapan koleksi keislaman di Perpustakaan UIN Sunan Kalijaga Yogyakarta.

Berdasarkan dari hasil reduksi data, peneliti menganalisa bahwa selain jasa dan layanan berbasis teknologi informasi serta didukung dengan kelengkapan studi keislaman, ada hal lain yang membuat jasa dan layanan di perpustakaan UIN Sunan Kalijaga Yogyakarta terkesan menarik. Hal itu diwujudkan dengan adanya kenyamanan ruang dan kelengkapan fasilitas seperti adanya wifi.

Jadi dari keseluruhan hasil reduksi data, dapat disimpulkan bahwa ditinjau lebih dalam terkait jasa dan layanan yang menarik dari Perpustakaan UIN Sunan Kalijaga adalah: (1) Koleksi studi keislaman; (2) Pelayanan mandiri berbasis teknologi informasi; (3) Kenyamanan ruang dan kelengkapan fasilitas. Berikut ini merupakan ilustrasi bentuk jasa dan pelayanan yang menjadi top product Perpustakaan UIN Sunan Kalijaga Yogyakarta.

\section{d. Evaluasi Kerja Organisasi}

Organisasi memiliki tim kerja dalam menunjang keberhasilan suatu tujuan.

Dengan adanya evaluasi yang benar-benar objektif terhadap kinerja organisasi yang terus menerus akan diketahui kekurangan dan keberhasilan yang telah dicapai sebagaimana dipaparkan oleh Siahaan (2008:84). Berdasarkan hasil reduksi data peneliti menganalisa bahwa evaluasi kerja organisasi di Perpustakaan UIN Sunan Kalijaga Yogyakarta dilakukan dengan rutin. Upaya yang dilakukan adalah dengan adanya forum rutin setiap satu bulan sekali dan melalui sebuah rapat kerja (raker) setiap akhir tahun.

Evaluasi ini diikuti oleh seluruh staf yang ada di perpustakaan.

Hasil analisa menunjukkan bahwa evaluasi kerja organisasi di Perpustakaan UIN Sunan Kalijaga merupakan upaya untuk meninjau kembali kerja tim yang sudah dilakukan. Selain meninjau kerja yang belum maksimal, Perpustakaan UIN sering mengevaluasi keberhasilan yang sudah di capai dan untuk memotivasi keberhasilankeberhasilan lain yang belum tercapai. 


\section{Gambar 3 Jasa dan Layanan di Perpustakaan UIN Sunan Kalijaga Yogyakarta}

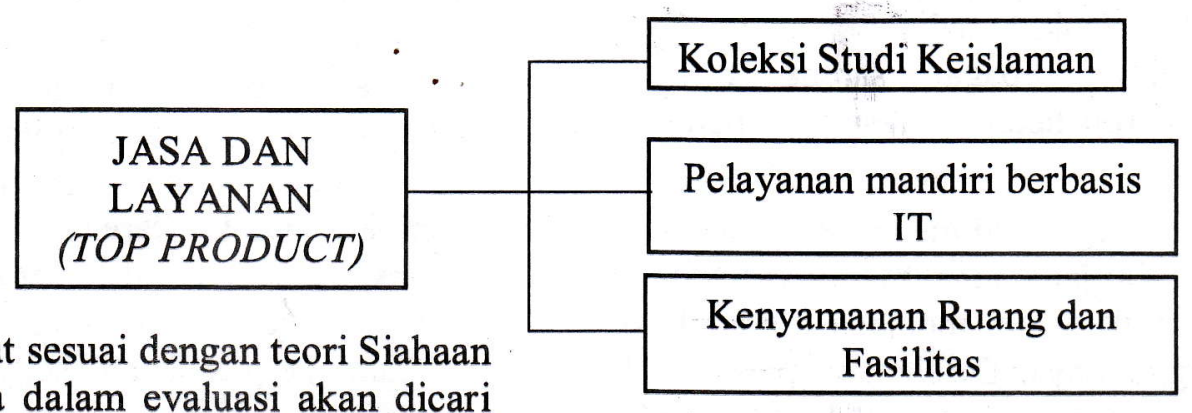

(2008:84) bahwa dalam evaluasi akan dicari kesalahanprosedur, kelemahan prosedur, kelemahan fasilitas yang ada, dan juga kelemahan ataupun kekurangan yang lain. Sehingga dari ini timCRM dapat membuat strategi CRM yang tepat dan dapat memperbaiki berbagaikelemahan yang ada.

Jika dilihat, berikut merupakan ilustrasi evaluasi kerja organisasi perpustakaan UIN Sunan Kalijaga Yogyakarta.

\section{Sisi Eksternal}

a. Komunikasi dengan Pengguna

\section{Perpustakaan}

Perpustakaan dibermanfaatkan secara penuh oleh penggunanya. Oleh karena itu komunikasi antar keduanya harus senantiasa terjalin dengan baik. Sebagaimana dipaparkan oleh Siahaan (2008: 84-85) bahwa Komunikasi dengan pelanggan bertujuan untuk mengeratkan hubungan dengan orangorang di luar lembaga atau instansi hingga terbentuklah opini publik yang favorable terhadap lembaga tersebut. Bagi suatu lembaga hubungan dengan publik di luar lembaga itu merupakan suatu keharusan di dalam usaha-usaha untuk menambah langganan, memperkenalkan jasa layanan, mencari modal dan hubungan, memecahkan persoalan atau kesulitan-kesulitan yang sedang dihadapi.

Berdasarkan hasil reduksi data, peneliti menganalisa bahwa pola komunikasi perpustakaan dengan pengguna terjalin secara langsung dan tidak langsung. Secara langsung merupakan komunikasi interpersonal seharihari antara petugas dengan pengguna perpustakaan. Sedangkan secara tidak langsung komunikasi antar keduanya terjalin melalui berbagai macam media. Hasil dokumentasi peneliti pada November 2014, berikut merupakan laman media sosial yang digunakan untuk menjaga komunikasi dengan pengguna seperti website perpustakan, digilib, facebook fans page, twitter, youtube channel, google+.

Dari reduksi data, peneliti menganalisa sebagian besar pengguna perpustakaan tidak hanya menjadikan media tersebut sebagai media komunikasi saja. Bahkan media tersebut dijadikan sarana untuk menyampaikan kritik, saran, masukan dan usulan yang membangun kerja organisasi.

\section{Gambar 4. Evaluasi Kerja Organisasi Perpustakaan UIN Sunan Kalijaga Yogyakarta}

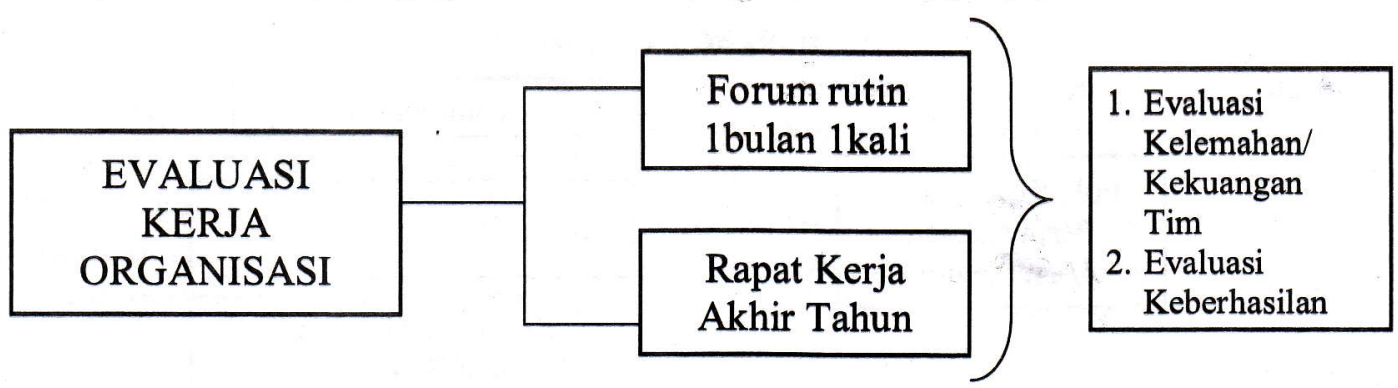


Hal ini menunjukkan bahwa pengguna perpustakaan juga berpartisipasi dan berperan penting dalam membangun kerja organisasi menjadi lebih baik. Media sosial tersebut terbukti efektif sebagai sarana diskusi pengguna perpustakaan dengan petugas perpustakaan.

Selain penggunaan media, Perpustakaan UIN Sunan Kalijaga juga memiliki strategi khusus dan unik dalam menjaga komunikasi dengan penggunanya. Disebutkan pada buku pedoman penggunaan perpustakaan (2014) bahwa perpustakaan UIN Sunan Kalijaga Yogyakarta memiliki sahabat perpustakaan yang siap membantu dan memberi informasi kepada pengguna perpustakaan.

\section{b. Sikap dan Performance}

Penilaian eksternal pelanggan terhadap suatu lembaga bukan saja mengenai pelayanannya, kegiatan-kegiatannya, tetapi juga mengenai keseluruhan komponen dari lembaga tersebut. Penampilan dari petugaspun, tentunya akan membuat penilaian tersendiri. Oleh karena itu, penampilan petugas, terutama yang berada di frontline tentunya akan membawa dampak pada penilaian perpustakaan secara keseluruhan dipaparkan oleh Siahaan (2008:85). Perpustakaan UIN Sunan Kalijaga memiliki upaya dalam membentuk sikap dan performa dalam pelayanan

\section{Gambar 6}

Sikap dan Performance petugas Perpustakaan UIN Sunan Kalijaga

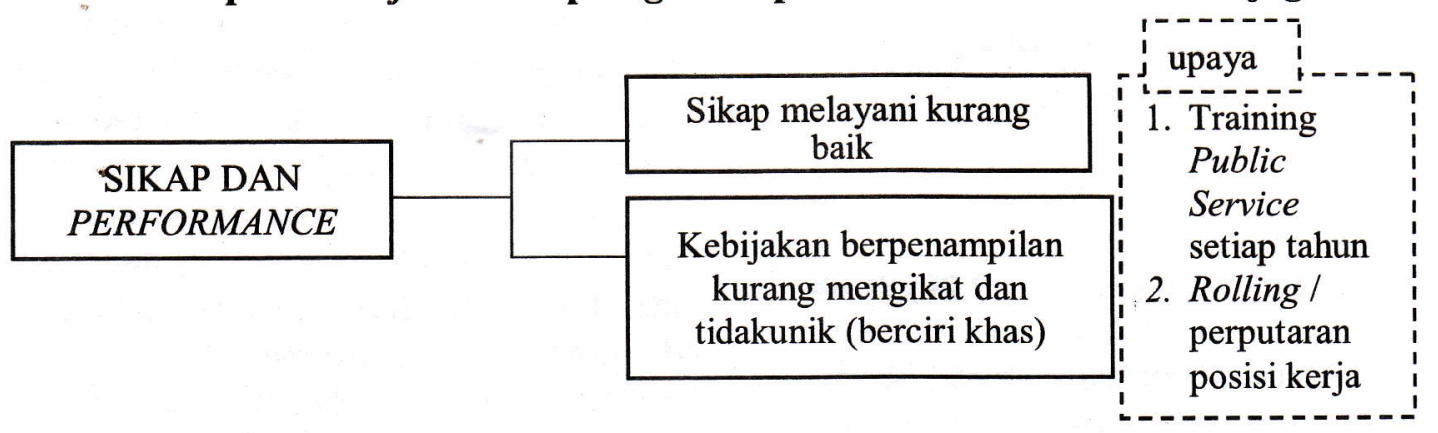

Dari hasil reduksi data peneliti menganalisa bahwa keberadaan mahasiswa partime atau dikenal dengan sahabat perpustakaan merupakan wujud pendayagunaan mahasiswa sebagai pengguna perpustakaan berubah menjadi partner kerja, sahabat dan tim yang menjembatani komunikasi perpustakaan dengan pemustaka agar tetap memanfaatkan layanan dan jasa Perpustakaan UIN Sunan Kalijaga Yogyakarta.

Maka jika diilustrasikan menjadi sebagai berikut.
Kemudian dipaparkan juga tentang performa petugas Perpustakaan UIN Sunan Kalijaga oleh EP (nama asli ada pada peneliti) sebagai berikut:

Jadi, dari keseluruhan hasil reduksi data peneliti menganalisa bahwa dari segi sikap dan performa Perpustakaan UIN senantiasa melakukan berbagai macam upaya untuk meningkatkan sikap dan performa petugas dalam pelayanan. Kebijakan dalam bersikap dan berpenampilan diterapkan namun masih bersifat kurang mengikat dan tidak ada sanksi

\section{Gambar 5 Pola Komunikasi Perpustakaan dengan Pengguna}

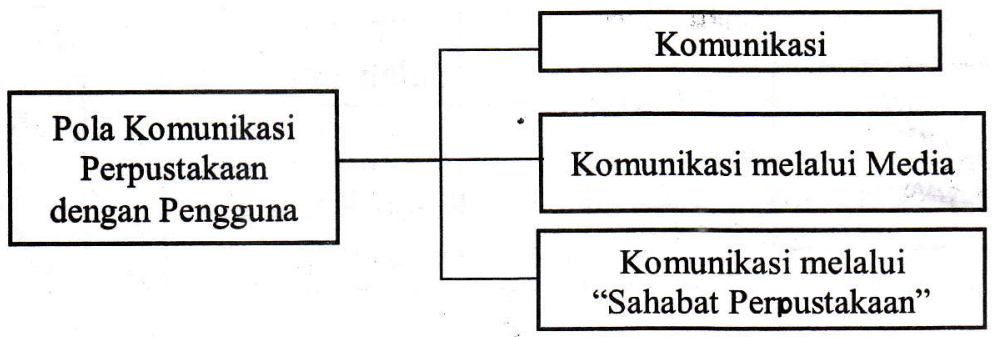


khusus dalam pelanggaran. Sehingga, hal ini membuat sikap dan performa dalam pelayanan terkesan kurang maksimal di hadapan publik.

Berikut jika diilustrasikan menjadi gambar diagram sikap dan performance petugas di Perpustakaan UIN Sunan Kalijaga Yogyakarta.

\section{c. Kerjasama Perpustakaan}

Kerjasama dalam sebuah kerja organisasi itu penting. Perpustakaan perlu menjalinhubungan yang baik dengan mitra kerja ataustakeholder. Kerja sama ini perlu senantiasadijalin, karena bagaimanapun suksesnya layanandi perpustakaan akan menguntungkan setiappihak, dan setiap pihak juga sama-samamemperoleh nilai tambah atau manfaat dankeuntungan atas terjalinnya mitra kerja danjaringan tersebut. (Siahaan, 2008:85). kerjasama sesama perpustakaan seperti Jogja Library For All, FKP2TN, FPPTI-DIY dan APPTIS.

Kemudian kerjasama dalam membentuk layanan corner seperti Iranian, Arabian dan Canadian.

Kerjasama yang dibentuk bersifat mutualisme atau saling menguntungkan satu sama lain. Dengan demikian dapat disimpulkan bahwa Perpustakaan UIN Sunan Kalijaga Yogyakarta menjalin kerjasama dengan berbagai pihak stakeholder. Kerjasamadari sesama perpustakaan, penerbit maupun lembaga-lembaga lainnya baik secara sponsorship maupun komersial.

\section{Gambar 7 Pola Kerjasama Perpustakaan UIN Sunan Kalijaga Yogyakarta}

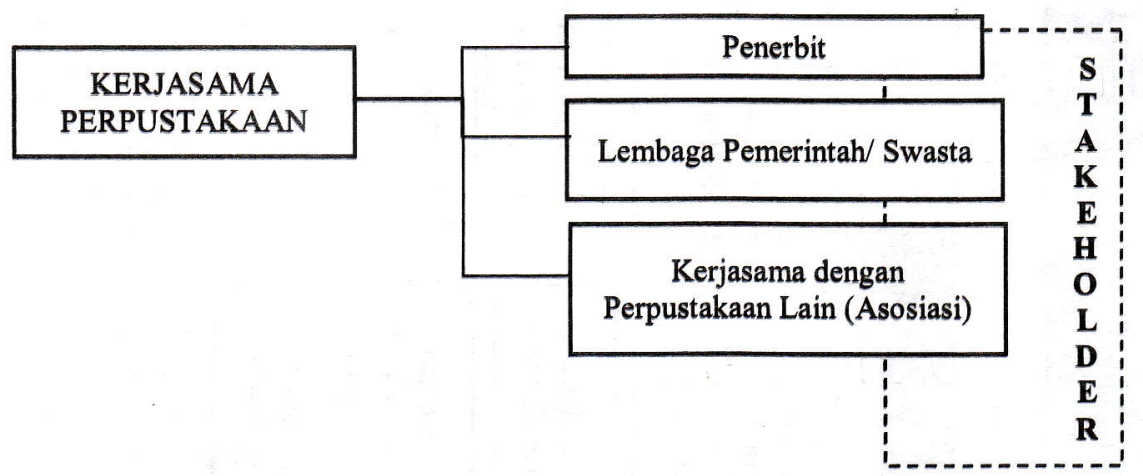

Berdasarkan hasil dokumentasi peneliti pada website aktif perpustakaan UIN Sunan Kalijaga Yogyakarta (http://www.lib/uinsuka.ac.id/2014) menunjukkan bahwa link kerjasama perpustakaan UIN Sunan Kalijaga meliputi Jogja Library For All, FKP2TN, FPPTI-DIY dan APPTIS.

Jadi, dari keseluruhan hasil reduksi data peneliti dapat menganalisa bahwa Perpustakaan UIN Sunan Kalijaga Yogyakarta menjalin kerjasama dengan penerbit, lembaga-lembaga pemerintah,
4.1 Peta Konsep Strategi Pemasaran dalam Upaya Membangun Loyalitas Perpustakaan UIN Sunan Kalijaga Yogyakarta Ditinjau dari Pendekatan Customer Relationship Management Strategi Pemasaran Dalam Upaya Membangun Loyalitas Pengguna di Perpustakaan UIN Sunan Kalijaga Yogyakarta Ditinjau dari Pendekatan Customer Relationship Management sudah dijelaskan secara rinci pada uraian di atas.Untuk dapat memahami hasil evaluasi strategi yang ada maka peneliti memperjelas hasil analisis menggunakan peta konsep yang tertera pada gambar 4.8 sebagai berikut. 


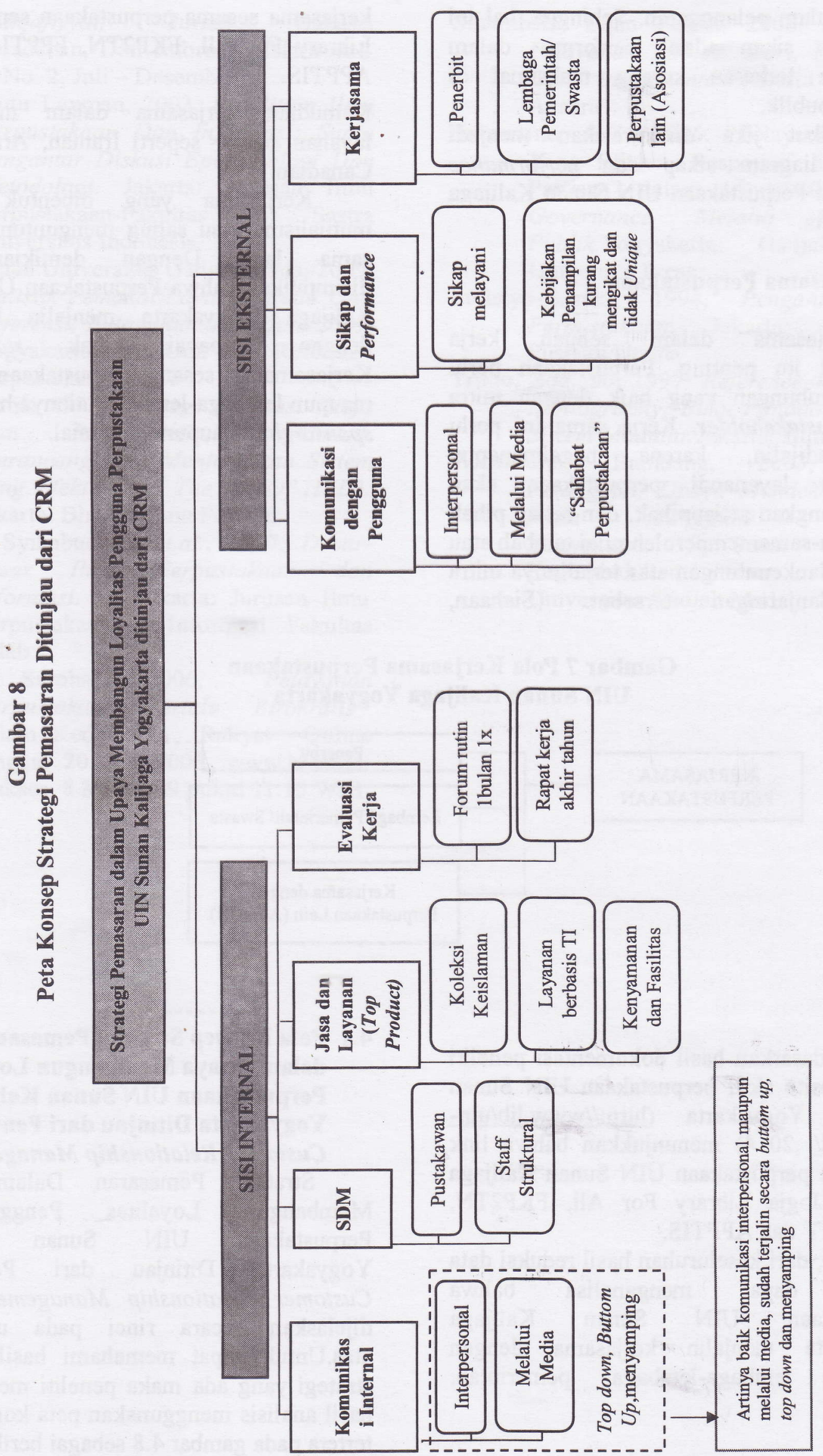


Jadi, dari peta konsep di atas dapat disimpulkan secara rinci bahwa hasil evaluasi strategi pemasaran dalam upaya membangun loyalitas pengguna di Perpustakaan UIN Sunan Kalijaga Yogyakarta ditinjau dari pendekatan Customer Relationship Management adalah sebagai berikut:

a. Komunikasi Internal terjalin secara top down, buttom up, dan menyamping secara interpersonal dan melalui media.

1) Komunikasi interpersonal

a) komunikasi sehari-hari;

b) forum pimpinan yang terdiri dari kepala, wakil dan koordinator bidang;

c) forum koordinasi yang terdiri dari kepala, koordinatoor bidang, dan koordinator urusan;

d) forum umum yang terdiri dari kepala dan seluruh pegawai yang bekerja di perpustakaan

2) Komunikasi melalui media

a) pesan memo dalam kondisi urgent,

b) melalui e-mail dan media sosial,

c) melalui telepon baik ponsel pribadi maupun telepon kantor

b. Sumber Daya Manusia di Perpustakaan

1) Kelompok Pustakawan, merupakan pustakawan yang sudah memiliki SK Kepustakawanan dari pemerintah, bekerja sesuai dengan petunjuk teknis profesi kepustakawanan serta rutin melakukan kegiatan pengembangan kompetensi kepustakawanan.

2) Staf Struktural, seluruh staf non pustakawan yang dipekerjakan oleh perpustakaan UIN Sunan Kalijaga Yogyakarta yang secara teknis bekerjasama dan dibina oleh kelompok pustakawan.

c. Jasa dan Layanan Unggulan (Top Product)

1) Pelayanan berbasis teknologi informasi, mengedapankan layanan mandiri secara tersistematis menggunakan teknologi demi efektivitas dan efisiensi.

2) Koleksi studi keislaman, mengedepankan koleksi studi keislaman sesuai dengan basic keislaman Universitas.
3) Fasilitas dan kenyamanan ruang, kelengkapan fasilitas seperti perabot dan desain tata ruang yang nyaman.

d. Evaluasi Kerja Organisasi

1) Forum rutin setiap bulan sekali, suatu forum yang mempertemukan antara pimpinan dan seluruh staf untuk melakukan evaluasi kerja baik permasalah positif maupun negatif dari perpustakaan guna perbaikan dan pengembangan layanan.

2) Rapat kerja akhir tahun, mengevaluasi program kerja yang sudah, sedang maupun belum berjalan pada satu tahun terakhir dan perencanaan program kerja pada satu tahun berikutnya.

2. Sisi Eksternal

a. Komunikasi Perpustakaan dengan Pengguna

1) Komunikasi interpersonal, yakni komunikasi secara langsung di lapangan.

2) Komunikasi melaui media, yakni pemanfaatan media sosial seperti akun facebook, twitter, yahoo chanel, googlet, kemudian adanya website resmi perpustakaan.

3) "Sahabat Perpustakaan", yakni pemanfaatan tenaga mahasiswa partime dalam shelving guna mempermudah temu kembali informasi serta jembatan komunikasi atau wadah infromasi pengguna tentang perpustakaan.

b. Sikap dan Performance petugas

1) Sikap dalam melayani petugas tidak ramah, tidak suka menolong, tidak tanggap kebutuhan sehingga dapat dikatakan kurang baik (lihat tabel hasil analisis kualitatif).

2) Performance, penampilan terkesan rapi namun kebijakan berpenampilan kurang mengikat dan tidak ada sesuatu yang menjadi ciri khas dari petugassehingga menimbulkan kesan tidak unik.

c. Kerjasama Perpustakaan 
Perpustakaan menjalin kerjasama dengan berbagai stakeholder baik dalam bentuk komersial maupun secara asosiatif.

1) Kerjasama dengan penerbit, secara komersial baik dalam pengadaan koleksi maupun dalam event-event tertentu.

2) Kerjasama dengan pemerintah maupun swasta, seperti dengan departemen agama, DIKPORA, perpustakaan sekolah dan sebagainya.

3) Kerjasama secara asosiatif, diwujudkan dengan adanya kerjasama antar perustakaan seperti Jogja Library For All, FKP2TN, FPPTI-DIY dan PPTIS.

\subsection{Analisis Data Kuantitatif}

Evaluasi strategi pemasaran dalam upaya membangun loyalitas pengguna di perpustakaan UIN Sunan Kalijaga Yogyakarta ditinjau dari Customer Relationship Management (CRM) telah dideskripsikan secara rinci pada penjelasan sebelumnya. Peta konsep hasil evaluasi juga sudah peneliti gambarkan pada penjelasan di atas. Untuk memperjelas hasil evaluasi strategi pemasaran Perpustakan UIN Sunan Kalijaga ditinjau dari ketujuh komponen CRM peneliti melampirkan hasil evaluasi secara kuantitatif dengan berpedoman pada pedoman evaluasi berdasarkan teori Siahaan (2008: 83-85). Hasil evaluasi secara kuantitas dapat dilihat pada penjelasan sebagai berikut:

Tabel 5 Hasil Evaluasi

\begin{tabular}{|c|c|c|c|c|c|c|}
\hline \multirow{2}{*}{ Standar } & \multirow{2}{*}{ * Variabel } & \multicolumn{2}{|r|}{ Indikator } & \multicolumn{2}{|c|}{ Keterangan } & \multirow[b]{2}{*}{ Skor } \\
\hline & & No & Content & $\begin{array}{c}\text { Terlak } \\
\text { sana }\end{array}$ & Tidak & \\
\hline \multirow{3}{*}{$\begin{array}{l}\mathbf{S} \\
\mathbf{I} \\
\mathbf{S} \\
\mathbf{I}\end{array}$} & \multirow[t]{3}{*}{ Komunikasi internal } & 1. & Top Down (kepala kepada karyawan) & & & 1 \\
\hline & & 2. & Bottom Up (karyawan kepada kepala) & $\sqrt{ }$ & & 1 \\
\hline & & 3. & $\begin{array}{l}\text { Menyamping (sesama karyawan dan/ atau sesama } \\
\text { kepala) }\end{array}$ & $\sqrt{ }$ & & 1 \\
\hline \multirow{17}{*}{$\begin{array}{l}\mathbf{I} \\
\mathbf{N} \\
\mathbf{T} \\
\mathbf{E} \\
\mathbf{R} \\
\mathbf{N} \\
\mathbf{A} \\
\mathbf{L}\end{array}$} & \multirow[t]{5}{*}{ Sumber Daya Manusia } & 4. & Keahlian (efektivitas kerja) & $\sqrt{ }$ & & 1 \\
\hline & & 5. & Kemampuan (produktifitas kerja) & $\sqrt{ }$ & & 1 \\
\hline & & 6. & Kekuatan (kesehatan badan dan psikis) & $\sqrt{ }$ & & 1 \\
\hline & & 7. & Pengalaman (keaktifan organisasi) & $\sqrt{ }$ & & 1 \\
\hline & & 8. & Potensi (pendidikan) & $\sqrt{ }$ & & 1 \\
\hline & \multirow[t]{8}{*}{ Jasa dan Layanan } & 9. & $\begin{array}{l}\text { Sesuai dengan kebutuhan/yang dikehendaki } \\
\text { pemakai. }\end{array}$ & $\sqrt{ }$ & & 1 \\
\hline & & 10. & Berlangsung cepat dan tepat sasaran & $\sqrt{ }$ & & 1 \\
\hline & & 11. & Menarik dan menyenangkan & $\sqrt{ }$ & & 1 \\
\hline & & 12. & Menimbulkan rasa simpati & $\sqrt{ }$ & & 1 \\
\hline & & 13. & Mengundang rasa ingin kembali & $\sqrt{ }$ & & 1 \\
\hline & & 14. & Mengembangkan hal-hal yang baru/ inovatif & $\sqrt{5}$ & & 1 \\
\hline & & 15. & $\begin{array}{l}\text { Bersifat informatif, membimbing dan } \\
\text { mengarahkan tetapi tidak bersifat menggurui }\end{array}$ & $\sqrt{ }$ & & 1 \\
\hline & & 16. & $\begin{array}{l}\text { Mampu menumbuhkan rasa percaya bagi pemakai } \\
\text { dan bersifat mandiri }\end{array}$ & $\sqrt{ }$ & & 1 \\
\hline & \multirow[t]{4}{*}{ Evaluasi Kerja Organisasi } & 17. & Evaluasi Team Kerja & $\sqrt{ }$ & & 1 \\
\hline & & 18. & Evaluasi Prosedur Kerja & $\sqrt{ }$ & & 1 \\
\hline & & 19. & Evaluasi Fasilitas & $\sqrt{ }$ & 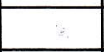 & 1 \\
\hline & & 20. & Evaluasi Hasil Program Kerja & $\sqrt{ }$ & & 1 \\
\hline
\end{tabular}




\begin{tabular}{|c|c|c|c|c|c|c|}
\hline \multirow{2}{*}{ Standar } & \multirow{2}{*}{ Variabel } & \multicolumn{2}{|r|}{ Indikator } & \multicolumn{2}{|c|}{ Keterangan } & \multirow{2}{*}{ Sko } \\
\hline & & No & Content & $\begin{array}{l}\text { Terlak } \\
\text { sama }\end{array}$ & Thoul: & \\
\hline \multirow{3}{*}{$\begin{array}{l}\mathbf{S} \\
\mathbf{I} \\
\mathbf{S} \\
\mathbf{I}\end{array}$} & \multirow[t]{8}{*}{$\begin{array}{l}\text { Komunikasi dengan } \\
\text { Pelanggan }\end{array}$} & 21. & $\begin{array}{l}\text { Komunikasi interpersonal (sapaan, tawaran } \\
\text { bantuan, dsb.) }\end{array}$ & $\sqrt{ }$ & & 1 \\
\hline & & 22. & Reward kepada pengguna paling rajin & & $\sqrt{ }$ & 0 \\
\hline & & 23. & $\begin{array}{l}\text { Mengkomunikasikan informasi tentang } \\
\text { perpustakaan (ter-uptodate) }\end{array}$ & $\sqrt{ }$ & & 1 \\
\hline \multirow{7}{*}{$\begin{array}{l}\mathbf{E} \\
\mathbf{K} \\
\mathbf{S} \\
\mathbf{T} \\
\mathbf{E} \\
\mathbf{R} \\
\mathbf{N} \\
\mathbf{A} \\
\mathbf{L}\end{array}$} & & 24. & Menanggapi keluhan pelanggan dengan baik & $\sqrt{ }$ & & 1 \\
\hline & & 25. & $\begin{array}{l}\text { Merealisasikan masukan-masukan yang } \\
\text { membangun }\end{array}$ & $\sqrt{ }$ & & 1 \\
\hline & & 26. & Media Komunikasi yang mendukung & $\sqrt{ }$ & & 1 \\
\hline & & 27. & $\begin{array}{l}\text { Kelayakan media yang dipakai (menyentuh seluruh } \\
\text { lapisan pengguna) }\end{array}$ & $\sqrt{ }$ & & 1 \\
\hline & & 28. & $\begin{array}{l}\text { Pemanfaatan media secara maksimal dalam } \\
\text { komunikasi }\end{array}$ & $\sqrt{ }$ & & 1 \\
\hline & \multirow[t]{5}{*}{ Sikapdan Performance } & 29. & Ramah (murah senyum, sapa, salam) & & $\sqrt{ }$ & 0 \\
\hline & & 30. & Suka menolong & & $\sqrt{ }$ & 0 \\
\hline \multirow[t]{5}{*}{ " } & & 31. & Tanggap dengan kebutuhan pengguna & & $\sqrt{ }$ & 0 \\
\hline & & 32. & Cerdas dalam melayani (cekatan) & $\sqrt{ }$ & & 1 \\
\hline & & 33. & Penampilan termanajemen & & $\sqrt{ }$ & 0 \\
\hline & \multirow[t]{2}{*}{ Kerjasama dan Jaringan } & 34. & $\begin{array}{l}\text { Kerjasama Komersial misalnya dalam pengadaan } \\
\text { (koleksi, perabot, perlengkapan) }\end{array}$ & $\sqrt{ }$ & & 1 \\
\hline & & 35. & $\begin{array}{l}\text { Kerjasama dengan perpustakaan lain (PT, Sekolah, } \\
\text { Umum, Khusus, dsb.) }\end{array}$ & $\sqrt{ }$ & & 1 \\
\hline & & & 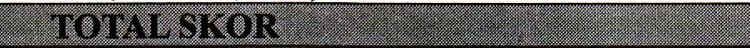 & & & Sis \\
\hline
\end{tabular}

Keterangan:

- Skor terlaksana $=1$

- Skor tidak terlaksana $=0$

Persentase kesesuaian objek penelitian dengan standart yang ada:

$$
\begin{aligned}
& \text { Persentase }=\frac{\text { Etotal Jawaban }}{\text { Skor Maksimal }} \times 100 \% \\
& \begin{array}{llll}
= & \frac{30}{35} & X & 100 \% \\
= & \mathbf{0 , 8 6} & \times & 100 \% \\
= & 86 \%
\end{array}
\end{aligned}
$$

Berikut merupakan standar ukuran untuk menentukan tingkat kesesuaian objek penelitian dengan standar evaluasi.
Tabel 6Konversi Tingkat Pencapaian

\begin{tabular}{ccc}
\hline $\begin{array}{l}\text { Persentase } \\
(\%)\end{array}$ & Kualifikasi & Keterangan \\
\hline $90-100 \%$ & Sangat Baik & Sangat Sesuai \\
\hline $75-89 \%$ & Baik & Sesuai \\
\hline $65-74 \%$ & Cukup & Cukup Sesuai \\
\hline $55-64 \%$ & Kurang & Kurang Sesuai \\
\hline $0-54 \%$ & $\begin{array}{c}\text { Sangat } \\
\text { Kurang }\end{array}$ & $\begin{array}{c}\text { Sangat Kurang } \\
\text { Sesuai }\end{array}$ \\
\hline & & Sudjana (2005:107).
\end{tabular}

Jadi, dapat disimpulkan bahwa Strategi pemasaran dalam upaya Membangun Loyalitas Pengguna Perpustakaan UIN Sunan Kalijaga Yogyakarta 86\% (sesuai) dengan konsep Customer Relationship Management. 


\subsection{Simpulan}

Berdasarkan penelitian dan pembahasan yang telah penulis lakukan maka dalam penelitian yang berjudul Evaluasi Strategi. Pemasaran dalam Upaya Membangun Loyalitas Pengguna di Perpustakaan UIN Sunan Kalijaga Yogyakarta Ditinjau Dari Customer Relationship Management dapat disimpulkan bahwa:

1. Pola komunikasi internal Perpustakaan UIN Sunan Kalijaga terjalin secara interpersonal dan melalui media

2. Sumber daya manusia di Perpustakaan UIN Sunan Kalijaga terdiri dari kelompok pustakawan dan staf struktural

3. Produk yang menjadi unggulan Perpustakaan UIN Sunan Kalijaga adalah layanan berbasis teknologi, koleksi keislaman, fasilitas dan kenyamanan ruang

4. Evaluasi kerja organisasi Perpustakaan UIN Sunan Kalijaga dilakukan dengan upaya membentuk forum rutin setiap bulan sekali dan rapat kerja setiap akhir tahun

5. Komunikasi dengan pengguna Perpustakaan UIN Sunan Kalijaga terjadi secara interpersonal, melalui media sosial dan melalui sahabat perpustakaan

6. Sikap dan performance petugas Perpustakaan UIN Sunan Kalijaga tergolong dalam taraf kurang baik dan kurang memperhatikan kebijakan berpenampilan

7. Perpustakaan UIN menjalin kerjasama luas dengan berbagai stakeholder.

Dengan demikian strategi pemasaran dalam upaya membangun loyalitas pengguna perpustakaan UIN Sunan Kalijaga Yogyakarta dinyatakan 86\% (sesuai) dengan konsep Customer Relationship Management.

\subsection{Saran}

Sesuai dengan tujuan dan manfaat penelitian, penelitian ini diharapkan memberi kontribusi terhadap institusi terkait. Oleh karena itu ada beberapa saran dan masukan dari penulis guna meningkatkan kesesuaian strategi pemasaran dengan konsep Customer
Relationship Management sehingga mampu mempertahankan loyalitas pengguna Perpustakaan UIN Sunan Kalijaga Yogyakarta. Adapun saran dari penulis adalah sebagai berikut:

1. Sebaiknya petugas perpustakaan khususnya petugas yang berada di depanlebih memperhatikan kebijakan berpenampilan seperti mengenakan seragam khas atau ID Card yang berciri khusus baik untuk pustakawan maupun staf struktural agar terkesan khas dan unik.

2. Sebaiknya petugas perpustakan lebih memperhatikan sikap dalam melayani seperti lebih ramah, tanggap kebutuhan, serta suka menolong agar tidak menimbulkan kekecewaan pada penggguna perpustakaan.

3. Sebaiknya perpustakaan memberikan reward kepada pengguna paling aktif agar pengguna mempertahankan loyalitas mereka terhadap perpustakaan.

\section{DAFTAR PUSTAKA}

Anderson, Kristin \& Carol Kerr. 2002. Customer Relationship Management. New York: McGraw-Hill.

Anonim. 2014. Website Perpustakaan UIN Sunan Kalijaga Yogyakarta. Diakses di http://www.lib.uin-suka.ac.id// pada 5 Desember 2014.

Arikunto, Suharsini. 2006. Prosedur Penelitian : Suatu Pendekatan Praktik.Jakarta : Rineka Cipta.

2010. Prosedur

Penelitian: Suatu Pendekatan Praktik. Ed.Revisi. Jakarta: Rineka Cipta.

Artana, I Ketut. 2003. "Perpustakaan, Masyarakat Dan Teknologi Informasi". Majalah Visi Pustaka Edisi Vol.5 No.2 Desember 2003. Diunduh di http://www.pnri.go.id/MajalahOnlineAd d.aspx?id=57 pada 18 Desember 2013.

Assauri, Sofjan. 2012. Stategic Marketing: Sustaining Lifetime Customer Value. Ed.1. Jakarta: Rajawali Pers. 
Boyd, Harper W; Orville C.Waker; Jean Claude Larreche. 2000. Manajemen Pemasaran: Suatu Pendekatan Strategis dengan Orientasi Global. Edisi Bahasa Indonesia. Jakarta: Erlangga.

Catalán-Matamoros, Daniel. 2012. Advances in Customer Relationship Management. Croatia: Janeza Trdine 9.

Griffin, Jill. 2005. Customer Loyality: Menumbuhkan dan Mempertahankan Kesetiaan Pelanggan. Jakarta: Erlangga.

Hadna, Ida Nur'aini dkk. 2014. Guide Book Perpustakaan UIN Sunan Kalijaga Yogyakarta (Edisi revisi). Yogyakarta: Perpustakaan UIN Sunan Kalijaga.

Irhamny, dkk. 2013. Guide Book Perpustakaan UIN Sunan Kalijaga Yogyakarta (Edisi revisi). Yogyakarta: Perpustakaan UIN Sunan Kalijaga.

Khomariah, Neneng. 2010. "Aplikasi Customer Relationship Management (CRM) D̉alam Layanan Informasi Di Perpustakaan".Artikel Ilmiah Pustaka UNPAD. Diunduh di http://pustaka.unpad.ac.id/archives/571 57/pada 17 September 2013 pukul 11.07 WIB

Kotler, Philip dan Kevin Lane Keller. 2007. Manajemen Pemasaran.Edisi 12 Bahasa Indonesia (Jilid 1). Jakarta: Indeks.

Lasa HS. 2005. Manajemen Perpustakaan. Yogyakarta: Gama Media.

Lucas, Robert W. 2005. Customer Service: Building Succesfull Skills for The Twenty-first Century. Third edition. New York: McGraw Hill Irwin.

Pemerintah Republik Indonesia. 2007. UndangUndang Nomor 43 Tahun Indonesia: Pemerintah Republik Indonesia.

Purwono. 2013. Profesi Pustakawan Menghadapi Tantangan Perubahan. Yogyakarta: Graha Ilmu.

Pustakawan. 2013. "Statistik Kunjungan Perpustakaan UIN Sunan Kalijaga Yogyakarta Tahun 2011,2012 dan 2013". Laporan. Yogyakarta: Perpustakaan UIN Sunan Kalijaga.
Sarwono. 2010. "Analisis Tentang Konsep Pemasaran Jasa Dan Relationship Marketing". dalam Jurnal elektronik INNOFARM: Jurnal Inovasi Pertanian Volume 9 Nomor 2 Tahun 2010.Diunduh http://ejournal.unisri.ac.id/index.php/inn ofarm/article/view/31 pada 08 November 2013 pukul 23.27 WIB.

Siahaan, Hotlan. 2008. "Costumer Relationship Management (CRM) sebagai Sarana Meraih Image Positif untuk Perpustakaan" Dalam Jurnal Elektronik PUSTAHA: Jurnal Studi Perpustakaan dan Informasi Volume 4 Nomor 2 Tahun 2008. Diunduh di http://puslit2.petra.ac.id/ejournal/index. php/pus pada 25 September 2013 pukul 21.20 WIB.

Sudjana, Nana. 2005. Penilaian Hasil Proses Belajar Mengajar. Bandung: PT. Remaja Rosdikarya.

Sugiyono. 2010. Metode Penelitian Kuantitatif Kualitatif dan $R \& D$. Bandung: Alfabeta.

Sulistyo-Basuki. 1993. Pengantar Ilmu perpustakaan. Jakarta: Gramedia.

Sunyoto, Danang. 2013. Dasar-dasar Manajemen Pemasaran: Konsep, Strategi dan Kasus. Yogyakarta: Caps.

Tjiptono, Fandy. 2014. Pemasaran Jasa: Prinsip, Praktik, Penelitian. Yogyakarta: Andi

Wirawan. 2012. Evaluasi: Teori, Model, Standar, Aplikasi, dam Profesi. Jakarta: Rajawali. 